\title{
무역을 위한 원조(Aid for trade)에 관한 회의결과
}

1. $\mathrm{OECD}$ 개발원조위원회는 금년 12 월 홍콩개최 제 6 차 $\mathrm{WTO}$ 각료회의 성공에 기여하기 위해 10.27 Aid for trade에 대한 특별회의를 개최하였음.

- Rantzien 주WTO 스웨덴대사, Rugwabiza WTO 사무차장, Manning 개발원조위원회 의 장이 공동주재하고, $\mathrm{OECD}$ 회원국의 무역 및 개 발담당관, 최빈국에 대한 무역관련기술지원을 위한 종합계획(IF) 회원국 대표, 국제금융기구 대표들이 참석

- 무역과 개발의 연계를 통해 빈곤감축에 기여한 사례로서 모잠비크 사례가 소개됨.

2. 의장단은 회의결과를 의장요약문 성격의 문서로 작성 발표하기를 희망하였으며, 참석자들은 문서 의 성격이 참가국의 commitment를 의미하지 않 는다는 전제하에 회의결과를 문서로 작성하는데 이의를 제기하지는 않았으며, 의장단은 회의결과 요약문에 대해, 참가국의 이견이 있을 경우
11.1(화)까지 보내줄 것을 요청함. 의장단이 요약 정리한 회의결과 요약문 요지는 다음과 같음.

ㅁ 금번 회의에서 무역을 위한 원조(aid for trade)의 효과를 증진하고 이러한 원조를 추진할 메카니즘으 로서 Integrated Framework(IF) 개선방안이 필요 하며, 무역관련 기술원조(TRTA)와 능력배양(CB)을 위한 $\mathrm{ODA}$ 의 확대가 필요하다는 점이 강조됨.

ㅁ 국제무역은 국내개혁과 함께 추진될 경우, 지속적 인 경제성장, 고용확대, 빈곤퇴치를 추진하기 위 한 강력한 엔진임. 그러나 개도국은 정책, 제도, 정보, 인프라 등 제분야에서 능력부족을 겪고 있 어 국제시장에서 효과적인 경쟁을 할 능력이 부족 하고, 국제무역이 제공하는 기회를 제대로 활용하 지 못하고 있음. 또한 개도국들은 무역통합에 따 르는 구조조정 압력을 관리할 자신들의 능력에 대 하여 우려하고 있는바, 개도국들은 선진국의 원조 를 잘 받을 경우, 도하패키지로부터 혜택을 볼 잠 재력을 가지고 있음. 
ㄱ 개도국의 빈곤완화전략에 무역부문이 포함되어야

함. 이를 위해서는 장애요인에 대하여 분석하고 이를 해결하기 위해서는 향후 확대되는 ODA중에 서 무역능력배양을 위한 추가적인 재정지원이 필 요함(OECD 사무국은 향후 ODA가 2004년도 800 억불에서 2010 년까지 1300 억불까지 확대될 것으로 전망).

ㅁㅏㅏㅁ석자들은 개도국의 무역능력배양의 중요성을 인정하고 이러한 능력을 강화하기 위해 특별한 조 치가 필요함을 인정함.

\section{가. IF 개선}

믐번 회의는 IF 강화를 위해 노력을 경주할 태스 크포스 설립을 환영함. 태스크포스의 핵심목표는 개도국들이 도하라운드에 의해 조성된 새로운 기 회를 포함하여 다이내믹한 국제무역에 참여하도 록 하기 위해 개도국 능력(local capacity)을 강화 하는 것임.

ㅁ참석자들은 태스크포스에 대한 적극적인 지원의 중요성에 합의함. 참석자들은 국가능력 강화, $\mathrm{IF}$ 지배구조 및 예산을 포함하여 다음과 같은 핵심분 야를 강조함.

- local ownership의 중요성, 그리고 국가적 무역 개발을 위한 과제 및 우선순위를 정하기 위하여 정책담당자와 민간기업, 연구기관, 시민단체간 협의채널 설립의 중요성

- IF의 성공적 운영을 위해 개도국과 공여국의 강 력한 리더쉽 필요

$-\mathrm{IF}$ 지원을 위한 예산은 다년도에 걸쳐 예측가능
하고 점차 증가하는 방식으로 지원

- 향후 진전사항을 모니터하고 국가적 경험을 공 유하는 과정이 $\mathrm{IF}$ 의 구성요소로 포함되어야 함. ㅁ 이와 관련, 파리선언에 명시된 바와 같이 원조효 과 증진이 기본적인 기준임.

\section{나. 광의의 aid for trade 과제}

ㅁ참석자들은 aid for trade 과제가 국가적 IF process 외에도 다양하게 존재함을 인정하고, 개 도국들이 다자무역체제에 통합되도록 하기 위한 환경을 조성해주는 것이 필요하며, aid for trade 를 위한 다양한 과제를 자세하게 정의할 필요가 있음을 강조함.

ㅁ 파리선언은 광의의 aid for trade 과제의 수행을 위하여 원조효과에 관한 벤치마크 대상이며 따라 서 무역 및 무역능력에 대한 지원은 개도국 주도 개발전략에 포함되어야 함.

ㅁㅏㅏㅁ석자들은 공여국이 천명한 $\mathrm{ODA}$ 규모의 확대계 획에 따라 aid for trade 사업에 대해서도 예산지 원 확대 가능성에 주목함.

\section{다. 홍콩각료회의 및 그 이후}

모다라운드의 자유화 패키지와 무역을 위한 원조 (aid for trade)가 상호 trade-off 또는 substitutes가 아니고 상호보완적인 성격임. 2001 년 도하라운드의 출범을 위해 개도국이 무역개혁 에 동의한 바, 지금은 선진공여국들이 무역, 개발, 빈곤완화를 위한 원조노력을 강화할 필요가 있음. ㅁ 공여국은 홍콩각료회의뿐만 아니라 그 이후에도 
무역능력배양 과제에 대한 지원 및 이행을 위하여 기여할 준비가 되어 있고, IF 개선에 전적으로 지 지하며, 광의의 aid for trade 과제를 모색하고 정 의하는데 지지함.

3. 동 회의 직전 개최된 제 142 차 무역위원회에서도 $\mathrm{DAC}$ 의장이 상기 문제에 대해 보고하였는 바, 일 본 대표는 IF 강화동향에 대해 제네바 협상 참석 자들이 보다 정확히 아는 것이 필요함을 지적하였 으며, 미국 대표는 능력배양/기술지원과 무역자유 화를 직접적으로 연계해서는 안된다는 입장을 표 명한 바 있음.

[자료:주오이시디 대표부] 